\title{
STUDY ON FACTORS AFFECTING THE PERFORMANCE OF CONSTRUCTION PROJECTS IN THE DEMOCRATIC REPUBLIC OF THE CONGO
}

\author{
B.F. Bitamba ${ }^{1 \#} \&$ S.H. An ${ }^{1 *}$
}

\section{ARTICLE INFO}

\section{Article details}

Submitted by authors 3 Jun 2019

Accepted for publication 25 Nov 2019

Available online 29 May 2020

\section{Contact details}

Corresponding author

shan@daegu.ac.kr

Author affiliations

1 Department of Architecture Engineering, Daegu University, South Korea

\# The author was enrolled for a PhD (Construction Management) degree in the Department of Architecture Engineering, Daegu University, South Korea

\section{DOI}

http: / /dx.doi.org/10.7166/31-1-2193

\section{ABSTRACT}

The Congolese construction industry faces many difficulties in dealing with the different factors that affect the proper performance of the construction process. Several key indicators (factors) that influence the construction performance in the Congo were selected for study and discussion. This study aimed to identify and evaluate the most significant key performance indicators that affect construction projects in the Congo, and to classify them using the relative importance index (RII). The most important factors affecting Congolese construction projects were design, client management, contractor productivity, scheduling, and the contract. The experience and skill of the design team were found to affect the design-related factors, whereas delayed payments and delivery of the construction site to the contractor were found to be the most important factors affecting client/owner-related factors. Client and management factors shared an equal average significant value of 0.68 , while the productivity scheduling and contract related factors for the contractor shared an equal average value of 0.67 . Finally, this work makes some recommendations to the Congolese construction industry in order to ensure proper project performance and successful projects.

\section{OPSOMMING}

Die Kongolese konstruksiebedryf ervaar vele uitdagings wat verband hou met die gewenste vertoning van die konstruksieproses. Verskeie sleutelindikatore wat die vertoning van konstruksieprojekte in die Kongo beïnvloed, word ondersoek en bespreek. Die doel van die studie is om die invloedrykste vertoningsindikatore te identifiseer, te evalueer en te klassifiseer deur 'n relatiewe belangrikheid-indeks. Die belangrikste faktore wat Kongolese konstruksieprojekte affekteer is ontwerp, kliëntbestuur, kontrakteurproduktiwiteit, skedulering en die kontrak. Die ervaring en vermoë van die ontwerpspan beïnvloed die ontwerp verwante faktore, waar vertraagde betalings aan en die beskikbaarheid van die konstruksieterrein vir die kontrakteur die belangrikste faktore is wat kliënt faktore affekteer. Kliënt- en bestuursfaktore dra 'n gelyke gewig van 0.68 terwyl die skedulering en kontrak verwante faktore 'n gewig van 0.67 dra. Ter afsluiting word aanbevelings vir die Kongolese konstruksiebedryf gemaak in 'n poging om projek vertoning te verbeter.

\section{INTRODUCTION}

The construction industry faces many problems, such as project overruns, time extensions, conflict among the parties, and the lack of a quality assessment system. The three main reasons that these problems are so widespread can generally be said to be the unique nature of projects, the fragmented and highly competitive nature of the construction industry, and the increasing challenges facing the industry. According to various studies, a construction project is commonly acknowledged as successful when it is completed on time, within budget, and in accordance with its quality specifications $[1,2,3]$. Rateb et al. [4] demonstrated that the project process was influenced by the difficulty of contractors in attracting financing. These authors revealed that financial difficulties faced by the contractor, manpower shortages 
(of skilled, semi-skilled, or unskilled labour), and excessive changes to the orders by owners were the leading factors directly affecting contractor performance on construction projects. Another study conducted by Boon et al [5] indicated that changes in the design and the amount of rework may lead to schedule delays and cost overruns [5]. This study demonstrated the serious impact of design changes on project performance through schedule and cost overruns [5]. The findings of this study revealed that design changes cause rework, while rework is the main cause of delays and disruptions in a project due to the loss of productivity. It is therefore vital to ensure that factors affecting construction project performance are dealt with so that scarce resources are directed where they are most needed. Once these factors are identified, the construction project's performance will be improved.

However, in the Democratic Republic of the Congo, many construction projects are completed late, or are never completed. Therefore, this study aimed to identify and evaluate significant performance indicators that affect construction projects according to the relevant stakeholders, categorised as owners, consultants, and contractors. A quantitative study was organised and a questionnaire prepared as the system to collect information from the main stakeholders involved in construction projects. After that, the relative importance index (RII) was used as a tool to classify the factors affecting construction projects' performance in the Congo.

\section{LITERATURE REVIEW}

\subsection{Factors affecting construction projects}

Several articles have studied the factors that affect the performance of construction projects in a number of ways. Some of the studies identified the most important factors in several countries and various project types, while other studies discussed the influence of these factors on the success and failure of construction projects, and proposed ways to improve and to minimise their influence on construction projects. A study carried out by Saleh et al. [6] revealed that the most important factors affecting construction project performance in Gaza were border and road closures, material shortages, unavailability of resources, a low level of project leadership skills, escalation of material prices, unavailability of highly experienced and qualified personnel, and poor quality of available equipment and raw materials. In Jordan, Nor et al. [7] acknowledged that financial difficulties faced by the contractor, manpower shortages (of skilled, semiskilled, or unskilled labour), and excessive changes to the orders by owners were the leading factors directly affecting contractor performance on construction projects.

A study conducted in Ethiopia by Abera et al. [2] showed that leadership performance problems were the major problems in Oromia Industry and Urban Development Bureau building construction projects. In the same study it was discovered that the key to the success of a construction project in Ethiopia was the involvement of a project manager (PM) to manage a construction project. In the same vein, a study in Malaysia revealed that the experience and proficiency of the design team had a significant influence on construction costs [7]. Boon et al. [5] and Mohamed et al. [8] discovered that multiple design changes were also found to be contributing factors causing rework in the construction project. Similarly, the authors discovered that adequate resource allocation and project leadership would improve timely project completion. However, it was noted that resource allocation cannot be the only concern of the stakeholders involved in a project. For this reason, Boon et al. [5] recommended that the Malaysian government ensure that there is adequate resource funding for all the projects they undertake. The authors added that, in addition to adequate resource funding, the government must develop and implement ways to reduce behaviours that promote corruption on funded government projects. Lastly, Boon et al. [5], along with Mohamed et al. [8] and Murithi et al. [9], recommended that time management be properly laid out in line with construction management principles, and that orders be delivered on time. This would contribute to the elimination of unnecessary construction delays in project completion.

The stability of construction materials' prices is important for proper cost management of the project. Studies conducted by Nor et al. [7] and Ghanim et al. [10] affirmed that the lack of construction materials influences the performance of a project. Moreover, these authors discovered that fluctuating material prices can lead to an increase in the cost of a construction project. In response to Nor et al. [7] and Ghanim et al. [10], Abera et al. [2] suggested that contractors predict the inflation of price materials, and that this be accounted for by the owners.

A study carried out in Ghana by Tengan et al. [11] revealed a lack of coordination between designers and contractors and poor monitoring and feedback to be factors that affect the quality performance of consultants. On the other hand, a lack of quality trained staff, leadership management, and previous 
experience were identified as the three factors related to contractors. A similar study conducted in Nigeria reported time completion, budget, and required quality as the top three criteria related to a contractor's performance [12]. A study in Benin added another view: that a construction company's productivity is largely dependent on production capacity and consumption of resources. This means that the retention of skilled workers and the use of high-quality resources yield the highest level of productivity $[13,14,15,16$, $17,18,19,20]$.

A study by Msafiri [21] revealed that client support helps to curb irregular fund disbursements and so minimise project delays and the stalling of construction projects. Furthermore, this study affirmed that client support enhances prompt payments and facilitates timely project completion. This author argued that client support helps in gaining expertise and the availability of client support, and enhances a contractor's performance in the construction sector. Finally, this author recommended that clients improve their financial management systems so that they are able to pay contractors on time.

On the other hand, a study conducted by Ugulu et al. [16] revealed safety performance to be significantly influenced by work organisation. This study recommended that the construction industry regularly review their safety training programmes by updating health and safety acts via in-company and on-site safety communications [16].

The quality of the organisation and management of a construction project may affect the project when it is not properly and fully administrated. Studies carried out by Msafiri [21] and Aynur et al. [22] revealed that worker productivity is very significantly affected by organisational factors [21, 22]. Another study stated that a contractor's experience and capability to finance a project will have a significant influence on the success of the project [23]. However, in Korea, Park et al. [24] discovered that the choice of a quality contractor was one of the most significant factors affecting Korean infrastructural projects.

A study carried out by Msafiri [21] revealed skilled manpower to be among the three principal factors influencing the performance of contractors in the road sector in Kenya [21].

Successful resource management requires an understanding of the lead time required to ensure that resources are available when needed. The optimal use of resources will lead to a reduction in project cost in an effective resource management programme, while poor resource management will cause the project to miss its scheduled targets and pose several issues such as cost escalation, material and labour wastages, and idling of machinery timings [8].

Furthermore, coordination among project participants can help to enhance the performance of construction projects, while the performance of refurbishment design can be improved by increased coordination among the key design participants in the projects $[25,26]$. Therefore, effective coordination among the key design participants will improve the management of refurbishing the design process. This will contribute to reducing project design changes during the construction stage [18].

Based on the literature review, this study selected 17 factors for their similarities with the Congolese environment and its social, economic, and political conditions. The authors considered that previous studies may also have an impact on the performance of construction projects in the Congo. For this reason, these factors were used to carry out the survey for the collection of quantitative data. The 17 factors in Table 2 were selected from 18 previous studies (the literature reviewed) shown in Table 1 with the following research titles. 
Table 1 Previous studies and publication years

\begin{tabular}{|c|c|c|c|}
\hline Studies & Research Titles & $\begin{array}{l}\text { Authors \& Publication } \\
\text { years }\end{array}$ & Ref. \\
\hline S1 & $\begin{array}{l}\text { Factors affecting performance of construction projects in unstable } \\
\text { political and economic situations }\end{array}$ & Ghanim, 2017 & [10] \\
\hline S2 & $\begin{array}{l}\text { Impact of environmental factors on building project performance in } \\
\text { Delta State, Nigeria }\end{array}$ & $\begin{array}{l}\text { Akamni, Oke } \\
\text { Akpomiemie, } 2015\end{array}$ & [27] \\
\hline S3 & Assessment of influencing factors in construction project scheduling & $\begin{array}{l}\text { Vidhyasri } \\
\text { Sivagamasundari, } 2018\end{array}$ & [28] \\
\hline S4 & $\begin{array}{l}\text { Factors influencing the construction cost of industrialized building } \\
\text { system (IBS) projects }\end{array}$ & $\begin{array}{l}\text { Sashitharan, Jusoh, Amlus, } \\
\text { Rahimi, Ibrahim \& Ismail, } \\
\text { 2014. }\end{array}$ & [29] \\
\hline S5 & ely completion of construction projects & $\begin{array}{l}\text { Murithi, Makokha \& Otieno, } \\
2017\end{array}$ & [9] \\
\hline S6 & $\begin{array}{l}\text { Factors affecting the performance of construction project under } \\
\text { Oromia Industry and Urban Development Bureau, Ethiopia }\end{array}$ & Abera \& Fekadu, 2016 & [2] \\
\hline S7 & $\begin{array}{l}\text { Critical factors affecting schedule performance: Evidence from } \\
\text { Indian construction projects }\end{array}$ & Iyer \& Jha, 2006 & [26] \\
\hline S8 & $\begin{array}{l}\text { Factors affecting quality performance of construction firms in } \\
\text { Ghana: Evidence from small-scale contractors }\end{array}$ & $\begin{array}{l}\text { Tengan, Anzagira, Kissi, } \\
\text { Balaara \& Anzagira, } 2014\end{array}$ & [11] \\
\hline 59 & $\begin{array}{l}\text { Factors influencing performance of contractors in the road } \\
\text { construction sector: Case of selected contractors in Kenya }\end{array}$ & Matu, 2016 & [30] \\
\hline S10 & $\begin{array}{l}\text { Significant factors causing cost overruns in the construction industry } \\
\text { in Afghanistan }\end{array}$ & Ghulam \& Noel, 2017 & [31] \\
\hline S11 & $\begin{array}{l}\text { Factors affecting contractor performance on public construction } \\
\text { projects }\end{array}$ & $\begin{array}{l}\text { Rateb, Sharaf, Korina \& } \\
\text { Ghaleb, } 2014\end{array}$ & [4] \\
\hline S12 & $\begin{array}{l}\text { Factors affecting the performance of construction projects in the } \\
\text { Gaza strip }\end{array}$ & $\begin{array}{l}\text { Saleh, Mohamed \& Enshassi, } \\
2009\end{array}$ & [6] \\
\hline S13 & $\begin{array}{l}\text { Factors affecting contractors' performance in construction project } \\
\text { delivery in Akure, Ondo State, Nigeria }\end{array}$ & $\begin{array}{l}\text { Olanipekun, Nunayon \& } \\
\text { Olugboyega, } 2017\end{array}$ & [12] \\
\hline S14 & $\begin{array}{l}\text { Performance of construction projects in the Gauteng Province of } \\
\text { South Africa: Insight of consultants and contractors }\end{array}$ & $\begin{array}{l}\text { Eke, Aigbavboa \& Thwala, } \\
2016\end{array}$ & [32] \\
\hline S15 & $\begin{array}{l}\text { Factors affecting the performance of construction projects: A survey } \\
\text { of construction projects in the coastal region of Kenya }\end{array}$ & Peter \& Evelyn, 2015 & [33] \\
\hline S16 & Factors affecting safety performance on construction sites & $\begin{array}{l}\text { Edwin, Shamil \& Daniel, } \\
1999\end{array}$ & [34] \\
\hline S17 & $\begin{array}{l}\text { Identification and assessment of risk factors affecting construc } \\
\text { projects }\end{array}$ & $\begin{array}{l}\text { Mohamed, Omar \& Ahmed, } \\
2017\end{array}$ & [1] \\
\hline S18 & Study of factors affecting performance of construction project & Saraf, 2015 & [35] \\
\hline
\end{tabular}


Table 2: Factors selected from previous studies

\begin{tabular}{|c|c|c|c|c|c|c|c|c|c|c|c|c|c|c|c|c|c|c|c|c|}
\hline No. & Factors & S1 & S2 & S3 & S4 & S5 & S6 & S7 & S8 & S9 & $\mathrm{S} 10$ & S11 & S12 & S13 & S14 & S15 & S16 & S17 & S18 & TOT \\
\hline 1 & Design & & & J & J & & J & & & & & & & J & J & J & & & & 6 \\
\hline 2 & Time & J & & & & & J & & & J & & & J & J & J & & & & & 6 \\
\hline 3 & Cost & J & & J & & & J & & & 2 & & & J & J & J & & & & & 7 \\
\hline 4 & Quality & J & & & & & J & & & J & & & J & J & J & & J & & J & 8 \\
\hline 5 & Productivity & J & & & & & J & & & & & & J & & & & & & J & 4 \\
\hline 6 & Client / Owner & J & & J & & & J & J & & J & J & J & J & J & J & & & & J & 11 \\
\hline 7 & Health \& safety & J & & J & & & & & & & & & J & J & J & J & J & & & 7 \\
\hline 8 & $\begin{array}{l}\text { Physical and } \\
\text { environmental conditions }\end{array}$ & & s & s & s & s & s & s & & s & s & s & s & & & s & s & s & s & 14 \\
\hline 9 & Project management & & & J & & & J & J & & J & & & & J & J & J & J & J & J & 10 \\
\hline 10 & Contractor & & & & J & J & J & & I & I & J & J & & J & J & & & S & & 11 \\
\hline 11 & Consultant & & & & J & J & J & & I & & J & J & & & & J & & & & 7 \\
\hline 12 & $\begin{array}{l}\text { Labour, equipment, and } \\
\text { material }\end{array}$ & & & s & & & s & & & s & & s & & & s & s & & s & s & 8 \\
\hline 13 & $\begin{array}{l}\text { Cash flow, economic, } \\
\text { and financial \& market } \\
\text { conditions }\end{array}$ & & r & s & s & r & s & & & r & & & & ऽ & s & & s & s & r & 11 \\
\hline 14 & Political & & J & J & & & & & & & & & & & & & & & & 2 \\
\hline 15 & $\begin{array}{l}\text { Social and cultural contri } \\
\text { bution }\end{array}$ & & s & s & & & & & & & & & & & & & & & & 2 \\
\hline 16 & $\begin{array}{l}\text { Legal, contract } \\
\text { procedures, and } \\
\text { authority requirements }\end{array}$ & & ᄂ & s & s & & ऽ & & & & & & & s & s & s & & & & 7 \\
\hline 17 & $\begin{array}{l}\text { Scheduling \& project rect } \\
\text { ification }\end{array}$ & & & s & & & s & & & & & & & & & s & & & & 3 \\
\hline
\end{tabular}


The 17 selected factors have been classified into two main categories. The first category is internal factors (Figure 1), which depend on the internal conditions of the project. This means that these factors can be controlled by the construction project manager (PM). The factors in the second category are external factors - those that depend on the external conditions of the project and are beyond the PM's or contractor's control. These factors are unpredictable, and management actions have not been able to prevent their occurrence. This study will mainly focus on the 12 category factors that constitute internal factors.

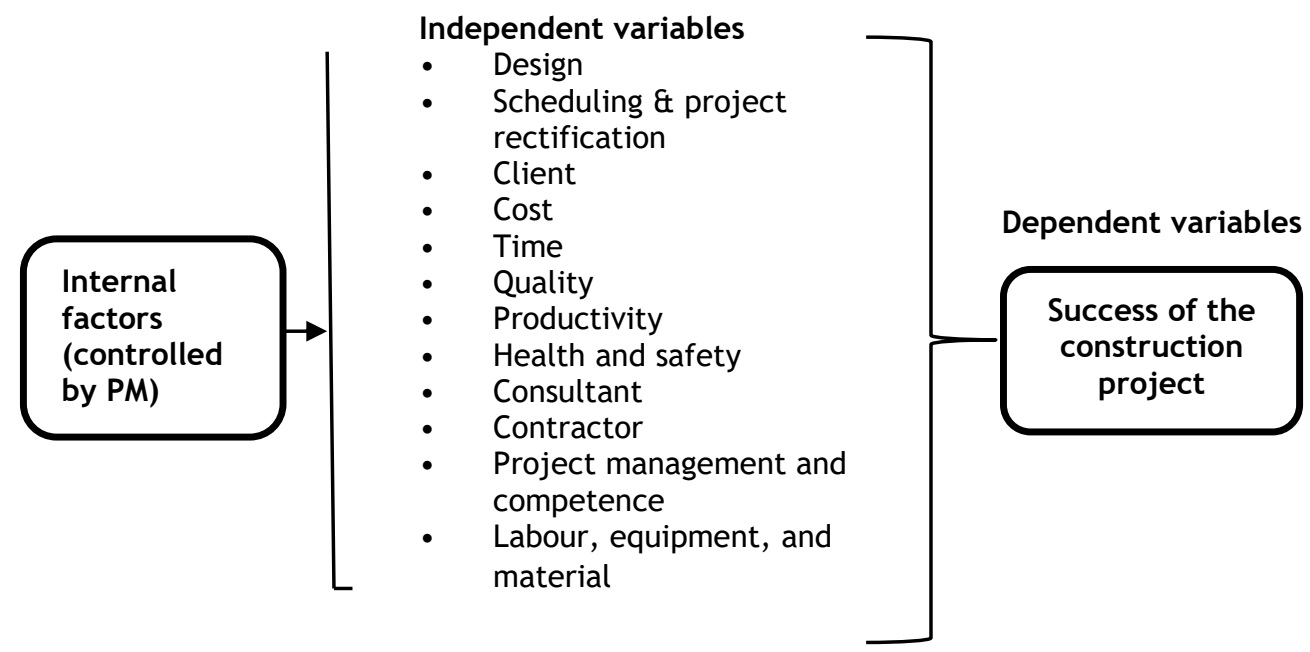

Figure 1: Presentation of internal factors

\section{METHODOLOGY}

A structured questionnaire survey approach was used to study, identify, and understand the impact of various factors affecting the performance of Congolese construction projects from different experienced respondents. The questionnaire was subdivided into two main sections. The first section included the characteristics and backgrounds of the participants and companies who contributed to the survey. The questions included the type of organisation, type of organisations' projects, company size in terms of the number of employees, job title of the respondents, working years of the respondents, number of projects executed by the respondents in the last five years, method used for project planning, and software applied for planning and scheduling the progress of the project.

The second section of the questionnaire included the factors controlled by the project manager that can $\mathrm{h}$ ave a considerable impact on performance in the Congolese construction industry. One hundred and seven factors (Table 3) affecting construction projects' performance were identified from the in-depth study of the literature (s1, s2, s3, etc.) and discussed with the main construction stakeholders (contractors, owners/clients, and consultants). These factors were then grouped into 12 major groups: design-related $f$ actors with six sub-factors, scheduling- and contract-related factors with four sub-factors, client-related $\mathrm{f}$ actors with 14 sub-factors, cost-related factors with nine sub-factors, time-related factors with eight subfactors, quality-related factors with six sub-factors, productivity-related factors with five sub-factors, hea Ith and safety-related factors with seven sub-factors, consultant-related factors with nine sub-factors, co ntractor-related factors with 13 sub-factors, project management and competence-related factors with 1 2 sub-factors, and labour, equipment, and material-related factors with 14 sub-factors.

One hundred questionnaires were administered to the three main stakeholder groups involved in the construction projects - contractors, owners, and consultants - in order to collect data. Fifty-three completed questionnaires were returned, representing a 53 per cent response rate. These questionnaires were based on a Likert's scale of five ordinal measures from 1 to 5 (very low importance to very high importance) according to the level of influence of these factors on the performance of the Congolese project. The returned questionnaires were received as follows: 16 (30 per cent) from owners, 19 (36 per cent) from consultants, and 18 (34 per cent) from contractors. Put differently, 39 (74 per cent) were from respondents in building projects, 10 (19 per cent) were in road projects, and four (seven per cent) were in 
water and sewage projects. The size of companies was classified by the number of labourers working in the project. The smallest size represented 26 (49 per cent) of the respondents; the medium size represented 19 (36 per cent) of the respondents, and the largest size had eight respondents (15 per cent).

Organisation managers made up 21 respondents or 39 per cent, followed by site engineers and office engineers ( 20 respondents, or 38 per cent), and finally project managers ( 12 respondents, or 23 per cent of all respondents)

Twenty-two respondents had 0-5 years' work experience, and represented 42 per cent of all the respondents; 15 , or 28 per cent of the respondents, had five to 5-10 years' work experience; 11 , or 21 per cent of the respondents, had more than 15 years' working experience; and finally, five, or nine per cent of the respondents, had 10-15 years' working experience. For the factor number of projects executed within the last five years, 1-10 were represented by 55 per cent of the respondents, followed by 21-30 that were represented by 19 per cent, 11-20 that were represented by 17 per cent, and nine per cent represented more than 30 executed projects within the last five years. Thirty-eight per cent of the respondents appeared not to use any project methods for project planning, 34 per cent used the bar chart method $(B C M), 17$ per cent were found to use the critical path method (CPM), and 11 per cent were found to use the line of balance method (LOB) for the planning of their projects.

Microsoft Project appeared to be the software most often used in planning and scheduling the progress of the project, with 20 respondents (38 per cent), followed by Excel Sheet Tool with 14 respondents ( 26 per cent), other tools with 10 respondents (19 per cent), and finally Primavera with nine respondents (17 per cent).

\section{RESULTS ANALYSIS}

The analysis was based on all the groups of respondents, with the key stakeholders categorised as contractors, consultants, and clients/owners. The respondents were asked to rate the level of the influence of these different factors on the performance of the construction projects in order to evaluate and identify the most significant key performance indicators of construction projects in the Congo.

In order to classify the factors influencing the performance of the construction projects, the relative importance index (RII) was used as a tool. This contributed to determining how each sub-factor had an impact on the construction process.

Table 2 gives detailed descriptions on how each sub-factor influenced the performance of the construction projects.

The data was analysed by calculating the relative important index (1) model to rank the hypothesised factors, which were derived from the views of the respondents of the three groups, based on their importance and frequency. This method has been used in many previous studies $[1,4,5,6,7,15]$ to determine the relative importance of the various factors affecting construction projects. The same method was adopted for this work.

The RII for each factor is calculated as shown below:

$$
\mathrm{RII}=\underset{(0>\mathrm{R} I I \leq 1)}{\sum \frac{\mathrm{W}}{\mathrm{A} N \mathrm{~N}}}
$$

where:

RII = relative importance index

$\mathrm{W}=$ weighting given to each factor by the respondents (ranging from 1 to 5 )

$A=$ highest weighting (i.e., 5 in this case); and

$\mathrm{N}=$ total number of respondents.

The RII values have a range of between 0 to 1 ( 0 not inclusive); the closer the RII result is to 1 , the more it affects its influence on the performance of the construction projects. The results of the RII analysis are shown in Table 3 below. 
Table 3: Field survey showing the results of the RII analysis

\begin{tabular}{|c|c|c|c|c|c|c|c|c|c|}
\hline \multicolumn{10}{|c|}{ Internal factors (controlled by the project management) } \\
\hline \multirow{3}{*}{ No. } & \multirow{3}{*}{$\begin{array}{l}\text { I. Factors related to design } \\
\text { Total average: } 0.69\end{array}$} & \multicolumn{8}{|c|}{ Organisation } \\
\hline & & \multicolumn{2}{|c|}{ Owner } & \multicolumn{2}{|c|}{ Consultant } & \multicolumn{2}{|c|}{ Contractor } & \multicolumn{2}{|c|}{ Average } \\
\hline & & RII & RANK & RII & RANK & RII & RANK & RII & RANK \\
\hline 01 & $\begin{array}{l}\text { Experience and proficiency of the } \\
\text { design team }\end{array}$ & 0.66 & 5 & 0.82 & 1 & 0.77 & 2 & 0.75 & 1 \\
\hline 02 & Error and changes in design & 0.7 & 2 & 0.58 & 5 & 0.79 & 1 & 0.69 & 2 \\
\hline 03 & Affects contract provision & 0.68 & 4 & 0.58 & 5 & 0.79 & 1 & 0.68 & 3 \\
\hline 04 & $\begin{array}{l}\text { Adjustment to contract price/contract } \\
\text { time }\end{array}$ & 0.69 & 3 & 0.68 & 2 & 0.66 & 4 & 0.68 & 3 \\
\hline 05 & Incorrectly implemented the first time & 0.66 & 5 & 0.6 & 4 & 0.67 & 3 & 0.64 & 5 \\
\hline 06 & \begin{tabular}{|l|} 
Project design complexity \\
\end{tabular} & 0.71 & 1 & 0.62 & 3 & 0.67 & 3 & 0.67 & 4 \\
\hline \multicolumn{10}{|c|}{$\begin{array}{l}\text { II. Factors related to time } \\
\text { Total average: } 0.64\end{array}$} \\
\hline 07 & Site preparation time & 0.68 & 2 & 0.63 & 5 & 0.56 & 6 & 0.62 & 3 \\
\hline 08 & Unofficial holidays & 0.64 & 4 & 0.44 & 7 & 0.51 & 8 & 0.53 & 6 \\
\hline 09 & Planned time for project construction & 0.71 & 1 & 0.74 & 2 & 0.6 & 4 & 0.68 & 3 \\
\hline 10 & Percentage of orders delivered late & 0.71 & 1 & 0.64 & 4 & 0.57 & 5 & 0.63 & 4 \\
\hline 11 & $\begin{array}{l}\text { Time needed to implement variation } \\
\text { in the orders }\end{array}$ & 0.66 & 3 & 0.66 & 3 & 0.52 & 7 & 0.61 & 5 \\
\hline 12 & $\begin{array}{l}\text { Average delay in claim approval and } \\
\text { payment from owner to contractor }\end{array}$ & 0.71 & 1 & 0.66 & 3 & 0.73 & 2 & 0.7 & 2 \\
\hline 13 & $\begin{array}{l}\text { Availability of resources as planned } \\
\text { through project duration }\end{array}$ & 0.64 & 4 & 0.81 & 1 & 0.74 & 1 & 0.73 & 1 \\
\hline 14 & $\begin{array}{l}\text { Average delay because of closures and } \\
\text { materials shortage }\end{array}$ & 0.68 & 2 & 0.57 & 6 & 0.63 & 3 & 0.62 & 3 \\
\hline \multicolumn{10}{|c|}{$\begin{array}{l}\text { Factors related to cost } \\
\text { Total average: } 0.60\end{array}$} \\
\hline 15 & Cost due to unofficial holidays & 0.55 & 7 & 0.47 & 7 & 0.37 & 8 & 0.46 & 7 \\
\hline 16 & \begin{tabular}{|l|} 
Cost of variation in the orders \\
\end{tabular} & 0.6 & 6 & 0.58 & 4 & 0.64 & 4 & 0.60 & 5 \\
\hline 17 & Profit rate of project & 0.66 & 2 & 0.67 & 2 & 0.71 & 1 & 0.68 & 1 \\
\hline 18 & Project overtime and overrun cost & 0.64 & 3 & 0.62 & 3 & 0.7 & 2 & 0.65 & 3 \\
\hline 19 & $\begin{array}{l}\text { Cost control system and motivation } \\
\text { cost }\end{array}$ & 0.63 & 4 & 0.56 & 6 & 0.67 & 3 & 0.62 & 4 \\
\hline 20 & Material, equipment, and labour cost & 0.69 & 1 & 0.70 & 1 & 0.63 & 5 & 0.67 & 2 \\
\hline 21 & \begin{tabular}{|l|} 
Escalation of material prices \\
\end{tabular} & 0.66 & 2 & 0.58 & 4 & 0.63 & 5 & 0.62 & 4 \\
\hline 22 & Delayed payment & 0.63 & 4 & 0.67 & 2 & 0.5 & 7 & 0.6 & 5 \\
\hline 23 & $\begin{array}{l}\text { Cost schedule associated with the } \\
\text { estimated time cost }\end{array}$ & 0.61 & 5 & 0.57 & 5 & 0.53 & 6 & 0.57 & 6 \\
\hline \multicolumn{10}{|c|}{$\begin{array}{ll}\text { IV. } & \text { Factors related to quality } \\
\text { Total average: } 0.66\end{array}$} \\
\hline 24 & Conforming to specification & 0.73 & 2 & 0.76 & 1 & 0.63 & 2 & 0.7 & 2 \\
\hline 25 & $\begin{array}{l}\text { Availability of persons with extensive } \\
\text { experience and qualifications }\end{array}$ & 0.75 & 1 & 0.67 & 2 & 0.43 & 5 & 0.61 & 4 \\
\hline 26 & $\begin{array}{l}\text { Quality of materials and equipment } \\
\text { used in the project construction }\end{array}$ & 0.75 & 1 & 0.76 & 1 & 0.59 & 3 & 0.7 & 2 \\
\hline 27 & $\begin{array}{l}\text { Quality assurance training and follow- } \\
\text { up }\end{array}$ & 0.71 & 3 & 0.66 & 3 & 0.78 & 1 & 0.71 & 1 \\
\hline 28 & $\begin{array}{l}\text { Participation of managerial levels in } \\
\text { decision-making }\end{array}$ & 0.63 & 4 & 0.67 & 2 & 0.59 & 3 & 0.63 & 3 \\
\hline 29 & $\begin{array}{l}\text { Quality assessment system in } \\
\text { organisation }\end{array}$ & 0.63 & 4 & 0.62 & 4 & 0.58 & 4 & 0.61 & 4 \\
\hline
\end{tabular}




\begin{tabular}{|c|c|c|c|c|c|c|c|c|c|}
\hline \multicolumn{10}{|c|}{ Internal factors (controlled by the project management) } \\
\hline \multirow{3}{*}{ No. } & \multirow{3}{*}{$\begin{array}{l}\text { V. Factors related to productivity } \\
\text { Total average: } 0.67\end{array}$} & \multicolumn{8}{|c|}{ Organisation } \\
\hline & & \multicolumn{2}{|c|}{ Owner } & \multicolumn{2}{|c|}{ Consultant } & \multicolumn{2}{|c|}{ Contractor } & \multicolumn{2}{|c|}{ Average } \\
\hline & & RII & RANK & RII & RANK & RII & RANK & RII & RANK \\
\hline 30 & Project complexity & 0.71 & $\underline{2}$ & $\underline{0.72}$ & 1 & 0.74 & $\underline{2}$ & $\underline{0.72}$ & 1 \\
\hline$\overline{31}$ & Number of new projects / years & $\overline{\overline{0.75}}$ & 1 & $\overline{\overline{0.64}}$ & 3 & 0.66 & $\overline{\overline{5}}$ & $\overline{\overline{0.68}}$ & 3 \\
\hline 32 & Management-labour relationship & 0.68 & 4 & 0.56 & 5 & 0.67 & 4 & 0.63 & 5 \\
\hline 33 & $\begin{array}{l}\text { Absenteeism rate throughout } \\
\text { project }\end{array}$ & 0.69 & 3 & 0.57 & 4 & 0.69 & 3 & 0.65 & 4 \\
\hline 34 & $\begin{array}{l}\text { Sequencing of work according to } \\
\text { schedule }\end{array}$ & 0.63 & 5 & 0.68 & 2 & 0.77 & 1 & 0.69 & 2 \\
\hline \multicolumn{10}{|c|}{$\begin{array}{l}\text { VI. Factors related to client/owner } \\
\text { Total average: } 0.68\end{array}$} \\
\hline 35 & $\begin{array}{l}\text { Speed and reliability of service to } \\
\text { owner }\end{array}$ & 0.68 & 3 & 0.74 & 1 & 0.74 & 6 & 0.72 & 2 \\
\hline$\underline{36}$ & $\begin{array}{l}\text { Delays in payments and delivery of } \\
\text { the site to the contractor }\end{array}$ & $\underline{0.71}$ & $\underline{\underline{2}}$ & $\underline{\underline{0.63}}$ & $\underline{\underline{8}}$ & $\underline{\underline{0.84}}$ & $\underline{\underline{1}}$ & $\underline{\underline{0.73}}$ & $\underline{\underline{1}}$ \\
\hline 37 & $\begin{array}{l}\text { Frequent change and additional work } \\
\text { during construction by client }\end{array}$ & 0.73 & 1 & 0.62 & 9 & 0.79 & 4 & 0.71 & 3 \\
\hline 38 & $\begin{array}{l}\text { Late in approving design and decision- } \\
\text { making }\end{array}$ & 0.68 & 3 & 0.64 & 7 & 0.77 & 5 & 0.7 & 4 \\
\hline 39 & $\begin{array}{l}\text { Finance and payments of completed } \\
\text { work }\end{array}$ & 0.61 & 6 & 0.73 & 2 & 0.82 & 2 & 0.72 & 2 \\
\hline 40 & Unrealistic imposed contract duration & 0.71 & 2 & 0.58 & 10 & 0.8 & 3 & 0.7 & 4 \\
\hline 41 & $\begin{array}{l}\text { Project completion date specified but } \\
\text { not yet planned by the owner }\end{array}$ & 0.68 & 3 & 0.62 & 9 & 0.72 & 7 & 0.67 & 7 \\
\hline 42 & $\begin{array}{l}\text { Financial constraints faced by the } \\
\text { owner }\end{array}$ & 0.71 & 2 & 0.65 & 6 & 0.72 & 7 & 0.69 & 5 \\
\hline 43 & $\begin{array}{l}\text { Insufficient coordination among the } \\
\text { parties by the owner }\end{array}$ & 0.66 & 4 & 0.58 & 10 & 0.63 & 10 & 0.62 & 10 \\
\hline 44 & $\begin{array}{l}\text { Delay in contractor's claims } \\
\text { settlements }\end{array}$ & 0.64 & 5 & 0.64 & 7 & 0.77 & 5 & 0.68 & 6 \\
\hline 45 & $\begin{array}{l}\text { Client emphasis on low construction } \\
\text { cost }\end{array}$ & 0.56 & 8 & 0.72 & 3 & 0.79 & 4 & 0.69 & 5 \\
\hline 46 & $\begin{array}{l}\text { Information and coordination between } \\
\text { owner and other projects' parties }\end{array}$ & 0.61 & 6 & 0.71 & 4 & 0.5 & 11 & 0.60 & 11 \\
\hline 47 & Client interference during construction & 0.56 & 8 & 0.65 & 6 & 0.7 & 8 & 0.63 & 9 \\
\hline 48 & $\begin{array}{l}\text { Client's ability to make project } \\
\text { decisions }\end{array}$ & 0.64 & 7 & 0.69 & 5 & 0.64 & 9 & 0.66 & 8 \\
\hline \multicolumn{10}{|c|}{$\begin{array}{l}\text { VII. Factors related to health and safety } \\
\text { Total average: } 0.52\end{array}$} \\
\hline 49 & $\begin{array}{l}\text { Implementation of health and safety } \\
\text { factors in organisation }\end{array}$ & 0.73 & 1 & 0.56 & 1 & 0.42 & 5 & 0.57 & 1 \\
\hline 50 & Accident rate reported in project & 0.68 & 2 & 0.48 & 4 & 0.44 & 4 & 0.53 & 3 \\
\hline 51 & $\begin{array}{l}\text { Site safety representative and safety } \\
\text { committee policy }\end{array}$ & 0.66 & 3 & 0.42 & 6 & 0.45 & 3 & 0.51 & 4 \\
\hline 52 & $\begin{array}{l}\text { Ongoing safety training and provision } \\
\text { of personal protective equipment }\end{array}$ & 0.61 & 6 & 0.53 & 2 & 0.5 & 2 & 0.55 & 2 \\
\hline 53 & Impact of Health and Safety Act & 0.66 & 3 & 0.46 & 5 & 0.38 & 6 & 0.5 & 5 \\
\hline 54 & Issue of safety booklet & 0.63 & 5 & 0.48 & 4 & 0.37 & 7 & 0.49 & 6 \\
\hline 55 & $\begin{array}{l}\text { Management-worker cooperation on } \\
\text { safety }\end{array}$ & 0.64 & 4 & 0.51 & 3 & 0.51 & 1 & 0.55 & 2 \\
\hline \multicolumn{10}{|c|}{$\begin{array}{l}\text { VIII. Factors related to project management } \\
\text { Total average: } 0.68\end{array}$} \\
\hline$\underline{\underline{56}}$ & $\begin{array}{l}\text { Authority to make day-to-day } \\
\text { decisions by the PM's team at site }\end{array}$ & $\underline{\underline{0.68}}$ & $\underline{\underline{3}}$ & $\underline{0.74}$ & $\underline{\underline{1}}$ & $\underline{\underline{0.79}}$ & $\underline{\underline{2}}$ & $\underline{\underline{0.74}}$ & $\underline{\underline{1}}$ \\
\hline 57 & $\begin{array}{l}\text { Developing and maintaining a short } \\
\text { and informal line of communication } \\
\text { among project team }\end{array}$ & 0.68 & 3 & 0.61 & 8 & 0.74 & 4 & 0.68 & 4 \\
\hline 58 & Construction control meetings & 0.68 & 3 & 0.69 & 4 & 0.78 & 3 & 0.72 & 2 \\
\hline
\end{tabular}




\begin{tabular}{|c|c|c|c|c|c|c|c|c|c|}
\hline \multicolumn{10}{|c|}{ Internal factors (controlled by the project management) } \\
\hline \multirow{3}{*}{ NO. } & \multirow{3}{*}{$\begin{array}{ll}\text { IX. } & \text { Factors related to project } \\
\text { management (continued) } \\
\text { Total average: } 0.68\end{array}$} & \multicolumn{8}{|c|}{ Organisation } \\
\hline & & \multicolumn{2}{|c|}{ Owner } & \multicolumn{2}{|c|}{ Consultant } & \multicolumn{2}{|c|}{ Contractor } & \multicolumn{2}{|c|}{ Average } \\
\hline & & RII & RANK & RII & RANK & RII & RANK & RII & RANK \\
\hline 59 & $\begin{array}{l}\text { Understanding operational difficulties } \\
\text { by the owner engineer, thereby taking } \\
\text { appropriate decisions }\end{array}$ & 0.64 & 5 & 0.67 & 5 & 0.71 & 7 & 0.67 & 5 \\
\hline 60 & $\begin{array}{l}\text { Availability of resources, funds, } \\
\text { machinery, material, etc. as planned } \\
\text { throughout the project duration }\end{array}$ & 0.55 & 8 & 0.62 & 7 & 0.72 & 6 & 0.63 & 8 \\
\hline 61 & $\begin{array}{l}\text { Top management's backing up the } \\
\text { plans and identifying critical activities }\end{array}$ & 0.58 & 7 & 0.63 & 6 & 0.72 & 6 & 0.64 & 7 \\
\hline 62 & $\begin{array}{l}\text { Technical incompetence and poor } \\
\text { organisational structure }\end{array}$ & 0.7 & 1 & 0.55 & 11 & 0.73 & 5 & 0.66 & 6 \\
\hline 63 & $\begin{array}{l}\text { Site management and improper } \\
\text { planning }\end{array}$ & 0.69 & 2 & 0.57 & 10 & 0.72 & 6 & 0.66 & 6 \\
\hline 64 & Project manager's technical capability & 0.69 & 2 & 0.71 & 2 & 0.81 & 1 & 0.74 & 1 \\
\hline 65 & $\begin{array}{l}\text { Understanding of responsibilities by } \\
\text { various project participants }\end{array}$ & 0.66 & 4 & 0.71 & 2 & 0.68 & 8 & 0.68 & 4 \\
\hline 66 & $\begin{array}{l}\text { Waiting for approval of tests and } \\
\text { inspections }\end{array}$ & 0.62 & 6 & 0.58 & 9 & 0.63 & 9 & 0.61 & 9 \\
\hline 67 & Leadership quality of $P M$ & 0.64 & 5 & 0.7 & 3 & 0.78 & 3 & 0.7 & 3 \\
\hline \multicolumn{10}{|c|}{$\begin{array}{l}\text { VII. Factors related to contractor } \\
\text { Total average: } 0.67\end{array}$} \\
\hline 68 & $\begin{array}{l}\text { Project team leader's commitment to } \\
\text { meet time and quality }\end{array}$ & 0.61 & 9 & 0.68 & 4 & 0.76 & 4 & 0.68 & 5 \\
\hline 69 & Budget progress monitoring & 0.59 & 10 & 0.69 & 3 & 0.79 & 3 & 0.69 & 4 \\
\hline 70 & $\begin{array}{l}\text { Experience and technical skill of } \\
\text { the project team leader }\end{array}$ & 0.66 & 5 & 0.72 & 1 & 0.74 & 5 & 0.70 & 3 \\
\hline 71 & $\begin{array}{l}\text { Project team leader's early and } \\
\text { continuous involvement in the } \\
\text { project }\end{array}$ & 0.63 & 8 & 0.68 & 4 & 0.81 & 2 & 0.70 & 3 \\
\hline 72 & $\begin{array}{l}\text { Project team leader's adaptability } \\
\text { to changes in the project plan }\end{array}$ & 0.65 & 6 & 0.68 & 4 & 0.82 & 1 & 0.71 & 2 \\
\hline 73 & $\begin{array}{l}\text { Implement an effective safety, } \\
\text { quality assurance program }\end{array}$ & 0.66 & 5 & 0.6 & 6 & 0.69 & 8 & 0.65 & 8 \\
\hline 74 & Control of subcontractors' work & 0.71 & 2 & 0.55 & 9 & 0.74 & 5 & 0.67 & 6 \\
\hline 75 & $\begin{array}{l}\text { Construction methods and mistakes } \\
\text { during construction }\end{array}$ & 0.65 & 6 & 0.57 & 7 & 0.71 & 7 & 0.64 & 10 \\
\hline 76 & $\begin{array}{l}\text { Late decision by the } \mathrm{A} / \mathrm{E} \text { design } \\
\text { consultant about design change }\end{array}$ & 0.61 & 9 & 0.56 & 8 & 0.71 & 7 & 0.63 & 9 \\
\hline 77 & $\begin{array}{l}\text { Lack of technical and experienced } \\
\text { manpower at site }\end{array}$ & 0.64 & 7 & 0.6 & 6 & 0.73 & 6 & 0.66 & 7 \\
\hline 78 & Financial difficulties by contractors & 0.7 & 3 & 0.70 & 2 & 0.74 & 5 & 0.71 & 2 \\
\hline$\underline{\underline{79}}$ & $\begin{array}{l}\text { Lack of sub-contractor skills, and } \\
\text { often changing sub-contractors }\end{array}$ & $\underline{\underline{0.74}}$ & $\underline{\underline{1}}$ & $\underline{\underline{0.70}}$ & $\underline{\underline{2}}$ & $\underline{\underline{0.76}}$ & $\underline{\underline{4}}$ & $\underline{\underline{0.73}}$ & $\underline{\underline{1}}$ \\
\hline 80 & $\begin{array}{l}\text { Ineffective coordination between } \\
\text { contractors and other parties }\end{array}$ & 0.69 & 4 & 0.61 & 5 & 0.58 & 9 & 0.63 & 9 \\
\hline \multicolumn{10}{|c|}{$\begin{array}{l}\text { VIII. Factors related to consultant } \\
\text { Total average: } 0.63\end{array}$} \\
\hline 81 & Absence of consultant's site staff & 0.65 & 3 & 0.55 & 8 & 0.68 & 4 & 0.63 & 4 \\
\hline 82 & $\begin{array}{l}\text { Lack of enough experience on the part } \\
\text { of the consultant }\end{array}$ & 0.63 & 5 & 0.56 & 6 & 0.63 & 6 & 0.60 & 6 \\
\hline 83 & Contract management problems & 0.71 & 1 & 0.63 & 4 & 0.69 & 3 & 0.68 & 1 \\
\hline 84 & $\begin{array}{l}\text { Slowness in giving instruction and poor } \\
\text { coordination between consultant and } \\
\text { parties }\end{array}$ & 0.64 & 4 & 0.69 & 2 & 0.6 & 8 & 0.64 & 3 \\
\hline 85 & $\begin{array}{l}\text { Consultants commitment to ensure con } \\
\text { struction work is done according to } \\
\text { specification }\end{array}$ & 0.66 & 2 & 0.72 & 1 & 0.57 & 9 & 0.65 & 2 \\
\hline 86 & $\begin{array}{l}\text { Consultant involvement to monitor } \\
\text { the project progress, and } \\
\text { cooperation to solve problems }\end{array}$ & 0.58 & 7 & 0.64 & 3 & 0.64 & 5 & 0.62 & 5 \\
\hline
\end{tabular}




\begin{tabular}{|c|c|c|c|c|c|c|c|c|c|}
\hline \multicolumn{10}{|c|}{ Internal factors (controlled by the project management) } \\
\hline \multirow{3}{*}{ NO. } & \multirow{3}{*}{$\begin{array}{ll}\mathrm{X} & \begin{array}{l}\text { Factors related to consultant } \\
\text { (continued) } \\
\text { Total average: } 0.63\end{array}\end{array}$} & \multicolumn{8}{|c|}{ Organisation } \\
\hline & & \multicolumn{2}{|c|}{ Owner } & \multicolumn{2}{|c|}{ Consultant } & \multicolumn{2}{|c|}{ Contractor } & \multicolumn{2}{|c|}{ Average } \\
\hline & & RII & RANK & RII & RANK & RII & RANK & RII & RANK \\
\hline 87 & $\begin{array}{l}\text { Delay in reviewing the design } \\
\text { documents }\end{array}$ & 0.55 & 8 & 0.56 & 7 & 0.61 & 7 & 0.57 & 7 \\
\hline 88 & Poor inspection plan by consultants & 0.64 & 4 & 0.63 & 4 & 0.76 & 1 & 0.68 & 1 \\
\hline 89 & $\begin{array}{l}\text { Inadequate quality assurance and } \\
\text { quality control plans }\end{array}$ & 0.61 & 6 & 0.6 & 5 & 0.7 & 2 & 0.64 & 4 \\
\hline \multicolumn{10}{|c|}{$\begin{array}{l}\text { VIII. Factors related to labour, equipment, and material } \\
\text { Total average: } 0.65\end{array}$} \\
\hline 90 & $\begin{array}{l}\text { Shortage of manpower (skilled, semi- } \\
\text { skilled, unskilled labour) }\end{array}$ & 0.6 & 9 & 0.67 & 4 & 0.76 & 2 & 0.68 & 4 \\
\hline 91 & Shortage of material and equipment & 0.66 & 6 & 0.74 & 1 & 0.77 & 1 & 0.72 & 1 \\
\hline 92 & Equipment and labour productivity & 0.74 & 1 & 0.70 & 2 & 0.7 & 4 & 0.71 & 2 \\
\hline 93 & Materials price fluctuations & 0.68 & 5 & 0.62 & 6 & 0.73 & 3 & 0.67 & 5 \\
\hline 94 & $\begin{array}{l}\text { Modifications in materials } \\
\text { specifications }\end{array}$ & 0.68 & 5 & 0.66 & 5 & 0.73 & 3 & 0.69 & 3 \\
\hline 95 & Insufficient, and failure of, equipment & 0.7 & 3 & 0.67 & 4 & 0.69 & 5 & 0.69 & 3 \\
\hline 96 & $\begin{array}{l}\text { Equipment choice and quality control } \\
\text { of materials }\end{array}$ & 0.7 & 3 & 0.70 & 2 & 0.66 & 7 & 0.69 & 3 \\
\hline 97 & $\begin{array}{l}\text { Project materials monopoly by some } \\
\text { suppliers }\end{array}$ & 0.68 & 5 & 0.68 & 3 & 0.64 & 8 & 0.67 & 5 \\
\hline 98 & $\begin{array}{l}\text { Lack of use of necessary modern } \\
\text { construction equipment }\end{array}$ & 0.7 & 3 & 0.67 & 4 & 0.69 & 5 & 0.69 & 3 \\
\hline 99 & $\begin{array}{l}\text { Weak motivation and conflict between } \\
\text { labour }\end{array}$ & 0.69 & 4 & 0.6 & 7 & 0.67 & 6 & 0.65 & 6 \\
\hline 100 & $\begin{array}{l}\text { Non-conforming and inappropriate use } \\
\text { of material }\end{array}$ & 0.71 & 2 & 0.55 & 9 & 0.58 & 9 & 0.61 & 7 \\
\hline 101 & $\begin{array}{l}\text { Poor procurement programming of } \\
\text { material }\end{array}$ & 0.63 & 7 & 0.57 & 8 & 0.57 & 10 & 0.59 & 8 \\
\hline 102 & Poor material handling on site & 0.61 & 8 & 0.53 & 10 & 0.46 & 12 & 0.53 & 9 \\
\hline 103 & Material theft \& damage & 0.63 & 7 & 0.62 & 6 & 0.53 & 11 & 0.59 & 8 \\
\hline \multicolumn{10}{|c|}{$\begin{array}{l}\text { IX. Factors related to scheduling \& contract } \\
\text { Total average: } 0.67\end{array}$} \\
\hline 104 & $\begin{array}{l}\text { Lack of cost planning/monitoring pre } \\
\text { and post contract stages }\end{array}$ & 0.63 & 3 & 0.65 & 1 & 0.71 & 2 & 0.66 & 2 \\
\hline 105 & $\begin{array}{l}\text { Inadequate review for drawings and } \\
\text { contract documents }\end{array}$ & 0.61 & 4 & 0.62 & 2 & 0.76 & 1 & 0.66 & 2 \\
\hline 106 & $\begin{array}{l}\text { Uncertainty by the supervising team in } \\
\text { dealing with the contractor's queries } \\
\text { resulting in delays }\end{array}$ & 0.65 & 2 & 0.62 & 2 & 0.69 & 3 & 0.65 & 3 \\
\hline$\underline{\underline{107}}$ & $\begin{array}{l}\text { Discrepancies between contract } \\
\text { documents }\end{array}$ & $\underline{\underline{0.7}}$ & $\underline{\underline{1}}$ & $\underline{\underline{0.62}}$ & $\underline{\underline{2}}$ & $\underline{\underline{0.76}}$ & $\underline{\underline{1}}$ & $\underline{\underline{0.69}}$ & $\underline{\underline{1}}$ \\
\hline
\end{tabular}

Table 2 presents the field survey showing the results from the RII analysis. According to the results, the internal group factors with the highest and most significant average RII values were the design-related factors with RII $=0.69$; client- and project management-related factors with RII $=0.68$; contractor, productivity, scheduling, and contract-related factors with RII $=0.67$; quality-related factors with RII = 0.66; labour, equipment, and material-related factors with RII $=0.65$; time-related factors with $\mathrm{RII}=0.64$; consultant-related factors with RII $=0.63$; cost-related factors with RII $=0.60$, and finally health and safetyrelated factors with RII $=0.52$. The criterion was then employed by ranking the highest and lowest subfactors within the group, with the highest rank indicating the ones that mostly affect the group factors, and vice versa.

According to these results, the experience and proficiency of the design team was ranked first, with RII = 0.75. This factor is important for these three stakeholders, because more experienced and competent designers will be more costly to clients. A previous study noted that contractors should consider the cost of design change when planning for the project; failing to do this may escalate the cost of the project [2]. Incorrectly implementing the design for the first time was ranked lowest, with RII $=0.64$. This was the lowest on the RII scale, yet even this was significant.

On the other hand, delays in payments and delivering the site to the contractor were found to be the most important factor that affects the owner/client performance, and it was ranked first with RII $=0.73$. It has 
been found that in the Congo, late payments by the project owner to the contractor and slowness in the delivery of building permits had a significant impact on the project client/owner's performance. Information and coordination between the owner and other project parties was ranked last, with RII $=0.60$. This indicates that in the Congo other project parties prefer communicating with the contractor rather than with the owner, making the assumption that the contractor is the key person to contact throughout the construction project's life cycle.

For the group factor 'management', the PM's team's authority to make day-to-day decisions at the site was ranked first, with RII $=0.74$. The lack of permanent implication of the project manager for the application of the project management policies, tools, and techniques was found to negatively influence Congolese construction project success. The authority of the PM's team to make day-to-day on-site decisions hindered the project's top management from performing. The lowest ranked sub-factor was waiting for approval for tests and inspections, with RII $=0.61$. This shows that late inspection and approval by the government and the Congolese building authority did not play a major role in affecting management. This was mainly because the Congolese project management body absolved itself of any responsibility for the timely inspection and approval by the government and the building authority. This meant that it was up to the government to conduct timely approvals of tests and inspections within the time they stipulated.

\section{CONCLUSION AND RECOMMENDATIONS}

This study determined the owners', consultants', and contractors' perceptions of the relative importance of key performance indicators affecting construction projects in the Congo. The findings present the top three internal key factors that were found to be the most significant. These are presented as design-related factors $(R=0.69)$, client/owner, and project management-related factors $(R I l=0.68)$, and contractor, schedule, and contract-related factors (RII=0.67).

In the design, experience and skill were found to have a greater effect, whereas delays in payments and delivery of the site to the contractor were the most important for the client/owner-related factors. The authority of the project manager's team to make day-to-day decisions at the site was found to be the most important item affecting the factors related to project management. The lack of sub-contractor skills and often changing sub-contractors also influenced the factors related to the contractor, while the complexity of the project was found to be the most important factor affecting productivity. Discrepancies between contract documents significantly affected the factors relating to schedules and contracts.

The result of this work motivates the authors to formulate recommendations to improve the performance of a construction project. One recommendation is that the Congolese construction industry ensure that all locals and foreigners working on a project are competent and possess enough experience to lead the project successfully. The government and the building authority should ensure the timely delivery of the construction site in order effectively to initiate the construction at the appropriate time to avoid mishaps and improper time management. Furthermore, the project manager and the owners should take more responsibility by making decisions about the proper performance of construction projects. Contractors should appoint qualified and experienced sub-contractors, and should provide them with continuous training programmes to improve their performance. This will help them to be more familiar with project management techniques and processes.

Stakeholders involved in construction projects in the Congo should understand the complexity of the projects to ensure successful construction project management. Finally, this paper recommends that consultants ensure that all contract discrepancies are found in time to prevent changes resulting from mistakes or errors between contract documents.

\section{ACKNOWLEDGEMENT}

This research was supported by the Daegu University Research Grant, 2017.

\section{REFERENCES}

[1] Mohamed, S.B.A.A.E., Omar, M.A.E.N. \& Ahmed, M.A.A. 2017. Identification and assessment of risk factors affecting construction projects. Housing and Building National Research Center Journal, 13(2), pp. 202-216.

[2] Abera, L.Y. \& Fekadu, T.Y. 2016. Factors affecting the performance of construction project under Oromia Industry and Urban Development Bureau, Ethiopia. ABC Research Alert Journal, 4(3).

[3] Murat, G., Mustafa, O. \& Yasemin, N. 2013. Quantification of Delay Factors Using the Relative Importance Index 
Method for Construction Projects in Turkey; Journal of Management in Engineering, 29(2):133-139.

[4] Rateb, J.S., Sharaf, M.B., Korina B. \& Ghaleb, S. 2014. Factors Affecting Contractor Performance on Public Construction Projects; Life Science Journal, 11(4s), pp 28-39.

[5] Boon, J.Y.H., Hamzah, A.R. \& Wang, C. 2017. Impacts of Design Changes on Construction Project Performance: Insights from A Literature Review; Journal of Quantity Surveying \& Construction Business,71, pp 31-54.

[6] Saleh, S.A.S., Mohamed, S. \& Enshassi, A. 2009. Factors Affecting the Performance of Construction Projects in the Gaza Strip; Journal of Civil Engineering and Management, 15(3), pp 269-280.

[7] Nor, A.A.B, Rosnah, Y., Napsiah, I., Aini J. \& Norizan, A. 2012. Factors Influencing the Construction Cost of Industrialised Building System (IBS) Projects; Social and Behavioral Sciences, 35, PP 689-696.

[8] Mohamed, M.A., Hossam, E.M. \& Mohamed, E.A.R. 2013. Evaluation of Change Management Efficiency of Construction's Contractors; Housing and Building National Research Center, 9(1), pp 77-85.

[9] Murithi, S.H, Makokha, E.N. \& Otieno, C. 2017. Factors Affecting Timely Completion of Public Construction Projects in Trans-Nzoia County; International Journal of Scientific and Research Publications, 7(4), pp 404-434.

[10] Ghanim, A.B. 2017. Factors affecting Performance of construction Projects in Unstable political and Economic Situations; ARPN Journal of Engineering and Applied Sciences, 12, pp 5384-5395.

[11] Tengan, C., Anzagira L.F., Kissi, E., Balaara, S. \& Anzagira, C.A. 2014. Factors Affecting Quality Performance of Construction Firms in Ghana: Evidence from Small-Scale Contractors; Civil and Environmental Research, 6(5), pp 18-23.

[12] Olanipekun, E.A., Nunayon, S.S. \& Olugboyega O. 2017. Factors Affecting Contractors' Performance in Construction Project Delivery in Akure, Ondo State, Nigeria; Journal of Knowledge Management, Economics and Information Technology, 7(4). www.scientificpapers.org.

[13] Agobe, R.K., Xin, F. \& Jing, Z. 2015. Construction Projects Productivity in West African country of Benin: Case of Ground Earthworks; Journal of Construction Engineering and Project Management, 5(2), pp 16-23.

[14] Chigara, B. \& Moyo, T. 2014. Factors Affecting Labor Productivity on Building Projects in Zimbabwe; International Journal of Architecture, Engineering and Construction, (3), pp 57-65.

[15] Wael A., Abubaker, A.A. \& Basel, S. 2019. Factors Affecting Construction Labour Productivity in Yemen; International Journal of Construction Management, 19(1), pp 79-91.

[16] Ugulu, R.A., Makhotso, M., Mahlatse, R., Morongoa, S. \& Allen S. 2016. The Influence of Motivation on Labour Productivity on Building Construction Projects in South Africa; International Journal of Scientific \& Engineering Research, 7(4), pp 1066-1073.

[17] Edwin, S., Shamil, N. \& Daniel, F.1999. Factors affecting safety performance on construction sites; International Journal of Project Management, 17(5), pp 309-315.

[18] Azlan, S.A. \& Ismail.R. 2009. Methods of Coordination in Managing the Design Process of Refurbishment Projects; Journal of Building Appraisal, 5(1), PP 87-98.

[19] Hafez, S.M., Aziz, R.F., Enas S.M., Madeha M.A. \& Eman, K.A. 2014. Critical factors affecting construction labor productivity in Egypt; American Journal of Civil Engineering, 2(2), P 35-40.

[20] Chaturvedi, S., Thakkar, J. \& Shankar, R. 2018. Labor Productivity in the Construction Industry Benchmarking: An International Journal, 25(1), PP 334-356.

[21] Msafiri, A.S. 2015. An Investigation into Factors Causing Delays in Road Construction Projects in Kenya; American Journal of Civil Engineering, 3(3), pp 51-61.

[22] Aynur K., Serdar U, \& Ekrem, M. 2008. Effect of Basic Motivational Factors on Construction Workforce Productivity in Turkey; Journal of Civil Engineering and Management, 14(2), pp 95-106.

[23] Jaman, I.A. \& Margaret, W.E. 2013. The Impact of Contractors' Attributes on Construction Project Success: A Post Construction Evaluation; International Journal of Project Management, 31(2), pp 313-322.

[24] Park, H.S. \& Kwon, S.W. 2011. Factor Analysis of Construction Practices for Infrastructure Projects in Korea; Journal of Civil Engineering, 15(3), pp 439-445.

[25] Wesam, S.A., Mohd, S.L. \& Noor, A.W.A.Z. 2016. Identification of Coordination Factors Affecting Building Projects Performance; Alexandria Engineering Journal, 55(3), pp 2689-2698.

[26] Iyer, K. \& Jha, K. 2006. Critical Factors Affecting Schedule Performance: Evidence from Indian Construction Projects; Journal of construction engineering and management, 132(8), pp 871-881.

[27] Akamni, P.O., Oke, A.E. \& Akpomiemie, O.A. 2015. Impact of Environmental Factors on Building Project Performance in Delta State, Nigeria; Housing and Building National Research Center Journal, 11(1), pp 91-97.

[28] Vidhyasri, R. \& Sivagamasundari, R. 2018. Assessment of Influencing Factors in Construction Project Scheduling; International Journal of Applied Engineering Research, 13(8), pp 5693-5699.

[29] Sashitharan, S., Jusoh, M.S., Amlus, M. H., Rahimi, A., Ibrahim, A.D.B.A., \& Ismail, M.S. 2014. Factors Influencing the Construction Cost of Industrialized Building System (IBS) Projects (Journal of Applied Science and Agriculture; 9(13), pp 6-13.

[30] Matu, J.M. 2016. Factors Influencing Performance of Contractors in the Road Construction Sector: Case of Selected Contractors in Kenya. A Research Project Report Submitted in Partial Fulfillment for the Requirements for the Award of the Degree of Master of Arts in Project Planning and Management, University of Nairobi (91 pages).

[31] Ghulam, A.N. \& Noel, P. 2017. Significant Factors Causing Cost Overruns in the Construction; Industry in Afghanistan. 7th International Conference on Engineering, Project, and Production Management, 182, pp 510 517.

[32] Eke, C.C., Aigbavboa C.O. \& Thwala, W.D. 2016. Performance of construction projects in the Gauteng Province of South: Insight of consultants and contractors, Proceedings of $12^{\text {th }}$ International Conference on Economics and Social Sciences (ICESS-2016).

[33] Peter, O.N. \& Evelyn, D. 2015. Factors Affecting the Performance of Construction Projects: A Survey of Construction Projects in the Coastal Region of Kenya; International Journal of Scientific and Research Publications, 5(10), pp 1-43. 
[34] Edwin, S., Shamil, N. \& Daniel, F. 1999. Factors affecting safety performance on construction sites; International Journal of Project Management, 17(5), pp 309-315.

[35] Saraf, D.D. 2013. Study of Factors Affecting Performance of Construction Project; International Journal of Science and Research (IJSR) ISSN (Online Index Copernicus Value Impact Factor, 14(5), pp 2319-7064. 